\title{
AUJESZKY'S DISEASE IN A DOG - CASE REPORT
}

\author{
Gospava Lazići ${ }^{1 \star}$, Tamaš Petrović ${ }^{1}$, Diana Lupulović ${ }^{1}$, \\ Bojan Topalski², Biljana Božićc ${ }^{1}$, Sava Lazić ${ }^{1}$ \\ ${ }^{1}$ Scientific Veterinary Institute „Novi Sad“, Novi Sad, Serbia \\ ${ }^{2}$ Veterinary ambulance NSVET, Novi Sad, Serbia
}

\section{Abstract}

This article reports on the occurrence and diagnosis of Aujeszky's disease in a dog. The procedure for isolation and identification of Aujeszky's disease virus was described. A dog of unknown breed aged about two years died of Aujeszky's disease after consuming animal offal (internal organs: lungs, spleen, kidneys) fed by the owner after slaughtering piglets and preparing meat for cooking. As early as 24 hours after consuming the offal, the dog manifested characteristic symptoms of Aujeszky's disease, which were immediately recognized by the veterinarian. The death occurred within less than 24 hours upon first clinical signs of disease. Aujeszky's disease virus was isolated and identified from brain and internal organ (lung and spleen) samples of the dog at the Department of Virology of the Scientific Veterinary Institute „Novi Sad“. Isolation and identification of the virus was performed on PK-15 porcine kidney cell line and using nested PCR technique.

Key words: Aujeszky's disease, dog, virus isolation and identification

\footnotetext{
${ }^{1 *}$ Corresponding author: goga@niv.ns.ac.rs
} 


\title{
AUJESKIJEVA BOLEST KOD PSA - PRIKAZ SLUČAJA
}

\author{
Gospava Lazići ${ }^{*}$, Tamaš Petrović ${ }^{1}$, Diana Lupulović ${ }^{1}$, \\ Bojan Topalski², Biljana Božićc ${ }^{1}$, Sava Lazić ${ }^{1}$ \\ ${ }^{1}$ Naučni institut za veterinarstvo „Novi Sad“, Novi Sad, Srbija \\ ${ }^{2}$ Veterinarska ambulanta NSVET, Novi Sad, Srbija
}

\section{Kratak sadržaj}

U radu je dat opis nastanka, razvoja i dijagnostikovanja Aujeskijeve bolesti kod psa. Opisan je postupak izolovanja i dokazivanja virusa Aujeskijeve bolesti. Pas nepoznate rase, uzrasta oko 2 godine uginuo je od Aujeskijeve bolesti nakon konzumiranja iznutrica (unutrašnji organi: pluća, slezina, bubrezi), koje je psu dao vlasnik nakon obrade prasadi i pripreme mesa za pečenje. Pas, je već 24 sata posle konzumiranja iznutrica ispoljio karakteristične simptome Aujeskijeve bolesti, što je veterinar, koji je pregledao psa odmah uočio. Uginuće psa je usledilo za nepunih 24 sata nakon ispoljavanja simptoma. Na Odeljenju za virusologiju, Naučnog instituta za veterinarstvo „Novi Sad“ iz uzoraka mozga i unutrašnjih organa (pluća i slezina) obdukovanog psa izolovan je i dokazan virus Aujeskijeve bolesti. Izolovanje i dokazivanje virusa Aujeskijeve bolesti vršeno je na kulturi ćelija PK-15 i upotrebom nested PCR tehnike.

Ključne reči: Aujeskijeva bolest, pas, izolovanje i dokazivanje virusa

\section{INTRODUCTION}

Aujeszky's disease (AD), also known as Pseudorabies, is an infectious disease caused by a Suid herpesvirus 1 (SHV-1) from the family Herpesviridae, subfamily Alphaherpesvirinae. The virus infects the central nervous system and other organs, such as respiratory tract of dogs, cats, cattle, sheep, rabbits, foxes, etc. Clinical signs do not occur in humans i.e. the disease is not zoonosis. Seroconversion has been reported, but there is no evidence that the virus replicates significantly or is shed from people (CFSPH, 2017). Pigs are considered as a natural host and the main reservoir of the virus but the characteristic clinical picture is manifested only in the suckling and sometimes in the weaned piglets. Aujeszky's disease in dogs was first described in Hungary in 1902. Pets can get infected by consuming contaminated raw pork meat. So far, there are 
no reports on direct dog-to-dog transmission. In dogs, after consuming meat contaminated with $\mathrm{AD}$ virus, the virus enters nerve endings in the mucosa and spreads to the brain along nerve axons (Kotnik et al., 2006). The incubation period is usually 2-6 days in the category of suckling pigs and less than 9 days in cattle and sheep. Reported incubation periods in dogs and cats range from 2 to 10 days, but most cases probably become apparent in 2-4 days (CFSPH, 2017). The infection of non-adapted species (such as dogs), results with death within few hours after showing of the first symptoms (Kotnik et al., 2006).

The diagnosis of Aujeszky's disease can be confirmed considering the observed clinical picture, epidemiological data and in the laboratory by virus isolation from the oro-pharyngeal fluid, nasal fluid (swabs) or tonsil swabs from living pigs, or from tissue samples (brain, tonsils, lung, mandibular and mediastinal lymph nodes) from dead pigs. On susceptible cell cultures, Aujeszky's disease virus induces cytopathogenic effect (CPE) within 24-72 hours. Polymerase chain reaction (PCR) is applicable for identification of the isolated virus. The PCR is based on the selective amplification of a specific part of the genome using two primers located at each end of the selected sequence. A realtime PCR has been developed for virus identification and differentiation between vaccinal and wild-type viruses based on specific detection of $\mathrm{gB}$ and $\mathrm{gE}$ genes. Virus neutralisation (VN) has been recognised as the reference method for serology, but for monitoring and surveillance diagnostic purposes it has been widely replaced by the enzyme-linked immunosorbent assay (ELISA) (Moennig et al., 1982; OIE, 2012).

There is no specific treatment for $\mathrm{AD}$, except supportive care and treatment for secondary infections (CFSPH, 2017). Specific control strategies for eradication of $\mathrm{AD}$ are conducted in pigs and are based on application of marker vaccines. The EU countries have successfully eradicated $\mathrm{AD}$ or have been conducting relevant programs for its eradication thus being considered $\mathrm{AD}$-free (COMMISSION DECISION 2008/185/EC). Accordingly, AD does not occur in most of the EU countries and is observed only in the population of wild boars, which are nowadays considered major virus reservoir in Europe (Meier et al., 2015). The disease has been identified in hunting dogs in Croatia after consumption of wild boar meat (Keros et al., 2015). Aujeszky's disease has also been reported in dogs in several European countries such as Hungary, Austria, Spain, Italy, Belgium and Croatia (Quiroga et al., 1998; Cay and Letellier 2009; Thaller et al., 2006; Sozzi i sar., 2012; Pizzurro et al., 2016).

The Aujeszky's disease is enzootic in swine population in Vojvodina region. Pušić and co-workers (2011) pointed out that AD intermittently occurs in the population of domestic pig in Vojvodina; however, it has been identified in 
another six animal species - cattle, sheep, dogs, cats, donkeys and badgers. All these species, except badgers, were in immediate contact with pigs or were fed with row pork meat. Previous serological surveys conducted in wild boar in Serbia were limited but suggested a relatively high AD seroprevalence (Lazić et al., 2015; Milićević et al., 2016).

The objective of this study is describing occurrence and clinical symptoms of $\mathrm{AD}$ in dog fed with pigs offal with no thermal treatment (internal organs: lungs, spleen, kidneys) and identification of $\mathrm{AD}$ virus from the sample material obtained at autopsy. Moreover, the aim is to describe the virus isolation and identification procedures using cell cultures and molecular methods (PCR).

\section{MATERIAL AND METHODS}

\section{Tissue samples}

The autopsy of the dog died with suspected clinical symptoms for $\mathrm{AD}$, and samples collection for laboratory testing's was performed at the Scientific Veterinary Institute „Novi Sad“. Based on the report of the veterinarian, rabies was excluded as the dog has previously been vaccinated several times, according to the Law of RS. At necropsy, focal pulmonary, gastric and renal hemorrhagies were recorded. The splenic pathology was particularly uniform, characterized by numerous dark-red to black, raised, soft, blood-filled areas of various sizes. Samples of brain tissue, lungs and spleen were collected for isolation of Aujeszky's disease virus. To the purpose of virus isolation, the samples were homogenized in Phosphate-buffered saline (PBS). Homogenates were centrifuged at $3000 \mathrm{xg}$ for $10 \mathrm{~min}$ and supernatants were filtrated through $0.45 \mu \mathrm{m}$ pore filters and used for inoculation. One of sample was prepared from pool of organs (lung and spleen) and second sample was the brain tissue.

\section{Virus isolation}

The virus isolation was performed on porcine kidney cell line (PK-15, ATCC CCL-33). From a 6-well cell culture plate (Sarstedt, Germany) with a monolayer of 24-hour old PK-15 cell line (of passage No: 164) (ATCC), the cells growing medium has been poured. Supernatants $(0.3 \mathrm{~mL})$ of both brain and organ samples (filtrate) were inoculated into two wells of culture plate each. The cells from remaining two wells were saved as a control. The inoculated culture plate was incubated for $60 \mathrm{~min}$ at $37 \pm 1^{\circ} \mathrm{C}$. After incubation, 3 $\mathrm{mL}$-aliquots of cell maintenance medium were added into each well and the 
plate was further incubated at $37 \pm 1^{\circ} \mathrm{C}$. Inoculated cells were observed daily for the occurrence of CPE using inversion microscope.

\section{Identification of isolated virus}

Identification of isolated virus has been performed by Polymerase Chain Reaction (PCR). From the supernatant and cell suspension with cytopathogenic effect, the DNA extraction was performed using commercial kit QIAamp DNA Mini Kit according to manufacturer's instruction (Qiagen, Germany).

A total of $5 \mu$ of sample DNA was used to run a PCR and nested PCR methods with "HotStar Taq Master Mix Kit" (Qiagen, Hilden, Germany) in $25 \mu \mathrm{l}$ reaction mixture volumes. The $\mathrm{gB}$ gene of $\mathrm{AD}$ virus was amplified using previously published oligonucleotide primers (Balasch et al., 1998). The size of the first stage PCR product was $334 \mathrm{bp}$. The second stage (nested) PCR product size was $195 \mathrm{bp}$. In both stages, primers were used at a concentration of 0.2 $\mathrm{mM}$, dNTPs at $200 \mathrm{mM}$ and Taq polymerase at $1 \mathrm{U}$ per reaction. The first stage of reaction consisted of 35 cycles of denaturation at $95^{\circ} \mathrm{C}$ for $60 \mathrm{~s}$, annealing at $60^{\circ} \mathrm{C}$ for $45 \mathrm{~s}$ and extension at $72^{\circ} \mathrm{C}$ for $30 \mathrm{~s}$. The second stage of reaction (nested PCR) consisted of 30 cycles of denaturation at $95^{\circ} \mathrm{C}$ for $60 \mathrm{~s}$, annealing at $65^{\circ} \mathrm{C}$ for $45 \mathrm{~s}$ and extension at $72^{\circ} \mathrm{C}$ for $30 \mathrm{~s}$. PCR products were visualized through UV light in a $2 \%$ agarose gel, stained with ethidium bromide.

\section{RESULTS AND DISCUSSION}

\section{The clinical signs of Aujeszky's disease}

A dog of unknown breed aged about two years was raised in the yard of owner, which fed the dog with piglet offal (lungs, spleen, kidneys) after slaughtering piglets and preparing meat for cooking. The day after consuming animal offal, the dog manifested unusual behaviour, and the owner referred to the veterinarian, who notices clinical signs of ataxia and scratching in the region of head and neck. Veterinarian had a suspicion on Aujeszky's disease and applied symptomatic treatment. The dog died on the same evening and the owner submitted the carcass to the Scientific Veterinary Institute „Novi Sad“on the next morning to excluding rabies as a potential cause of death.

\section{Virus isolation}

Cytomorphological changes indicating multiplication of Aujeszky's disease virus (occurrence of big circular cells with extensions on the margins of the 
monolayer where cells were completely destroyed) were observed on porcine kidney cell line (PK15) in both plate wells 48 hours after brain tissue inoculation. Cytomorphological changes on cell cultures inoculated with internal organ samples were observed some 72 hours post inoculation. Throughout next few days, cytomorphological changes have been even more pronounced. On $5^{\text {th }}$ day characteristic cytomorphological changes involved about $90 \%$ cells in each well of the inoculation plate. There were no changes on cells in two PK-15 cells control wells.

\section{Identification of isolated virus}

Aujeszky's disease virus was identified from the supernatant and suspension of cells with cytopathogenic effect using nested PCR method. Besides afore mentioned sample of PK-15 cells with obvious CPE (inoculated with brain sample of died dog), nine samples of aborted pig foetuses negative for $\mathrm{AD}$ virus were also included in the reaction. The obtain nested PCR product of $195 \mathrm{bp}$ was visualized in $1.5 \%$ agarose gel with $0.5 \mu \mathrm{g} / \mathrm{ml}$ ethidium bromide solution (Fig.1).

Figure 1: Cytomorphological changes (cytopathogenic effect) as a result of Aujeszky's disease virus replication on cell cultures PK-15 and positive virus finding with nested PCR technique as the method for virus confirmation

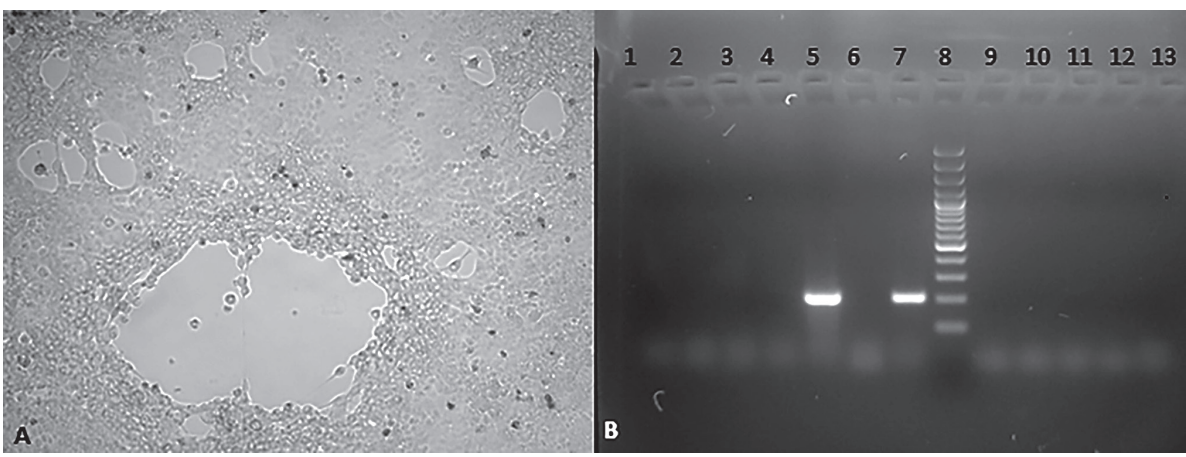

A - Cytopathogenic effect: circular cells with cellular extensions on the margins cellfree layer

B - nested PCR products (from left to right): 1 - 4 - tissue samples of negative aborted pig fetuses; 5 - positive brain sample from dog; 6 - negative control (water); 7- positive control; 8 - 100bp DNA ladder; 9-13 negative tissue samples of aborted pig fetuses. 
Aujeszky's disease is widely present on pig farms in the Republic of Serbia, and only few of them are AD-free (Pušić et al., 2011; Prodanov-Radulović et al., 2015). Research in this study is in accordance with a range of studies worldwide, which confirmed presence of $\mathrm{AD}$ in dogs. The disease was reported in Austria and Germany in 2006 and 2009, respectively. These are the first cases of Aujeszky's disease since 1997, when the disease was eradicated in these countries (Thaller et al., 2006; http://www.promedmail.org/post/20100107.0067). Sozzi and collaborators (2012) in Italy, offered an interesting insight into genomic characterization of the strains of Aujeszky's disease virus - clear differentiation between strains isolated from hunting dogs, which were similar to those isolated from wild boars and strains isolated from dogs on the farms, which were similar to those affecting domestic pigs. Moreover, in Italy in 2014, a virus was detected in a 7-year old hunting dog that was in contact with blood of wild boar. The AD virus was detected and isolated by real-time PCR and rabbit kidney cell culture (RK13) (Pizzurro et al., 2016). In 2007, in Belgium, Aujeszky's disease was confirmed by the methods of virus isolation (PK-15) and real-time PCR in two hunting dogs manifesting characteristic clinical symptoms. The identified strains were highly pathogenic for dogs, and strains that have previously been isolated from wild boars strongly indicated that the virus circulates among the wild boar population even though there were no reports on virus transmission to domestic pigs (Cay and Letellier, 2009). Aujeszky's disease was confirmed in 7 dogs in Spain (1995) as well as in 13 dogs in Beijing, China in the period 2011-2013 (Quiroga et al., 1998; Zhang et al., 2015).

\section{CONCLUSIVE REMARKS}

Clinical signs of Aujeszky's disease are easily recognizable. Laboratory diagnostic methods like virus isolation and PCR detection of Aujeszky's disease virus, used in this study further facilitate the diagnosis of the disease. Aujeszky's disease virus was isolated on cell culture and identified from the supernatant and suspension of cells with cytopathogenic effect using nested PCR method.

Feeding domestic carnivores with fresh, no thermal treatment pork meat, poses a great risk for the occurrence of $\mathrm{AD}$ in such animals. Accordingly, uncontrolled feeding domestic carnivores with fresh pork meat can result in occurrence and spreading of Aujeszky's disease among the population of domestic animals. 


\section{ACKNOWLEDGEMENTS}

This investigation was supported by a grant from the Ministry of Education, Science and Technological Development of the Republic of Serbia, Project No. 31084.

\section{REFERENCES}

1. Balasch M., Pujols J., Segalés J., Pumarola M.: Aujeszky’s disease (pseudorabies) virus detection in cerebrospinal fluid in experimentally infected pigs. Veterinary Microbiology, 1998, 60, 2-4, 99-106.

2. Cay A.B. and Letellier C.: Isolation of Aujeszky's disease virus from two hunting dogs in Belgium after hunting wild boar. Vlaams Diergeneeskundig Tijdschrift, 78, 194-195, 2009.

3. CFSPH: The Center for Food security \& Public Health, Iowa State University and Institute for International Cooperation in Animal Biologics, Iowa State University, 2017.

4. COMMISSION DECISION 2008/185/EC, of 21 February 2008, on additional guarantees in intra-Community trade of pigs relating to Aujeszky's disease and criteria to provide information on this disease.

5. Keros T., Jemeršić L., Brnić D., Prpić J., Dežđek D.: Pseudorabies in hunting dogs in Croatia with phylogenetic analysis of detected strains. Veterinary Record Case Reports, 3: e00181. doi:10.1136/vetreccr-2015-000181, 2015.

6. Kotnik T., Suhadolc S., Juntes P., Gombač M., Toplak I., Hostnik P., Malovrh T., Barlič-Maganja D., Grom J.: Case report of a Pseudorabies (Aujeszky's disease) in a bitch. Slovenian Veterinary Research, 43, 3, 143-145, 2006.

7. Lazić S., Milićević V., Lazić G., Veljović L., Lupulović D., Prodanov-Radulović J., Maksimović-Zorić J., Grubač S., Došen R., Petrović T.: A serological survey on Aujeszky's disease in wild boars in the region of Vojvodina in Serbia. Proceedings, First International Symposium of Veterinary Medicine 'One Health - New Challenges' (ISVM2015), Vrdnik, May 21-23, 2015, editor in chief Tamaš Petrović, Novi Sad, Scientific Veterinary Institute 'Novi Sad', 2015, 290-294, ISBN 9978-86-82871-36-1.

8. Meier R.K., Ruiz-Fons F. and Ryser-Degiorgis M.P.: A picture of trends in Aujeszky's disease virus exposure in wild boar in the Swiss and European contexts. BMC Veterinary Research, 11, 277, 2015.

9. Milićević V., Radojčić S., Valčić M., Ivović V., Radosavljević V.: Evidence of Aujeszky's disease in wild boar in Serbia. BMC Veterinary Research, 12, 134, 2016. 
10. Moennig V., Woldesenbert P., Fey H.R., Liess B., Dopotka H.D. \& Behrens F.: Comparative evaluation of ELISA and neutralization test for the diagnosis of Aujeszky's disease. In: Current Topics in Veterinary Medicine and Animal Science 17. Aujeszky's Disease, Wittmann G. \& Hall S.A., eds. Martinus Nijhoff, The Hague, The Netherlands, 51, 1982.

11. O.I.E Manual of Diagnostic Tests and Vaccines for Terrestrial Animals, 2012., Chapter 2.1.2

12. Pizzurro F., Mangone I., Zaccaria G., De Luca E., Malatesta D., Innocenti M., Carmine I., Cito F., Marcacci M., Di Sabatino D., Lorussob A.: Wholegenome sequence of a suid herpesvirus-1 strain isolated from the brain of a hunting dog in Italy. Genome Announcements, 4, 6, e01333-16, 2016.

13. Prodanov-Radulović J., Došen R., Pušić I., Petrović T., Apić J., Stojanov I., Polaček V.: Emergence of pseudorabies virus (Morbus Aujeszky) infection at large swine farms in AP Vojvodina (Serbia). Contemporary agriculture, 105-111, 2015.

14. Pušić I., Prodanov-Radulović J., Došen R., Stojanov J., Stojanović D., Petrović T.: Epizootical characteristics of Aujeszky's disease in Vojvodina region and biosecurity concerns. Biotechnology in Animal Husbandry, 27, 875-882, 2011.

15. Quiroga M.I., Nieto J.M., Sur J., Osorio F.: Diagnosis of Aujeszky's disease virus infection in dogs by use of immunohistochemistry and in-situ hybridization. Transboundary and Emerging Diseases, 45, 1-10, 75-81, 1998.

16. Sozzi E., Moreno A., Lelli D., Cinotti S., Alborali G.L., Nigrelli A., Luppi A., Bresaola M., Catella A., Cordioli P.: Genomic Characterization of Pseudorabies Virus Strains Isolated in Italy. Transboundary and Emerging Diseases, 61, 334-340. 2014.

17. Thaller D., Bilek A., Revilla-Fernández S., Bagó Z., Schildorfer H., Url A., Weikel J., Weissenböck H.: Diagnosis of Aujeszky's disease in a dog in Austria. Wiener Tierarztliche Monatsschrift, 93, 3, 62-67, 2006.

18. Zhang L., Zhong C., Wang J., Lu Z., Liu L., Yang W., Lyu Y.; Pathogenesis of natural and experimental Pseudorabies virus infections in dogs. Virology Journal, 12:44, doi:10.1186/s12985-015-0274-8, 2015.

Primljeno: 24.07.2017.

Odobreno: 13.09.2016. 
